\title{
Money supply, inflation and output: an empirically comparative analysis for Vietnam and China
}

\author{
Pham Dinh Long and Bui Quang Hien \\ Ho Chi Minh City Open University, Ho Chi Minh City, Vietnam, and \\ Pham Thi Bich Ngoc \\ Hoa Sen University, Ho Chi Minh City, Vietnam
}

Money supply, inflation and output

eceived 25 March 2021

Revised 14 May 2021 Accepted 5 July 2021

\begin{abstract}
Purpose - This study focuses on analyzing the relation between money supply, inflation and output in Vietnam and China.

Design/methodology/approach - Using the error correction model and the vector autoregression model (ECM and VAR) and the canonical cointegration regression (CCR), the study shows similar patterns of these variable relations between the two economies.

Findings - The study points out the difference in the estimated coefficients between the two countries with different economic scales. While inflation in Vietnam is strongly influenced by expected inflation and output growth, inflation in China is strongly influenced by money supply growth and output growth.

Originality/value - To the best of the authors' knowledge, this is the first empirical and comparative research on the relation between money supply, inflation and output for Vietnam and China. The study demonstrates that the relationship between money supply, inflation and output is still true in case of transition economies.
\end{abstract}

Keywords Money supply, Inflation, Output, Monetary policy

Paper type Research paper

\section{Introduction}

During economic transition, China has been considered a leader among socialist countries that have successfully transformed the economic model from a planned economy to a marketoriented economy. Economic reform is urgent and under pressure when the economy suffers serious crises. This reform is similar in Vietnam, but Vietnamese reform is 10 years later than Chinese one (1978 in China, 1986 in Vietnam) (Ma, 1999; Dao and Vu, 2008). It can be said that economic reform in China has provided some experience and creates motivation for many countries to conduct similar transitions. However, China and Vietnam are the only two countries that have been transformed from a planned economy to a market-oriented economy while keeping their own orientations. In the 1980s, apart from changing the political system, the Soviet Union and Eastern European countries have shifted to the market economy. In the area of monetary policy, China and Vietnam also have a thorough transition from one-tier bank system - which holds full control of the national financial system to two-tier bank system - by splitting into central banks and commercial banks, providing credit services for specific industries (Ma, 1999; Oanh, 2001; Dao and Vu, 2008). This change helps the

JEL Classification - E3, E45, O11

(C) Pham Dinh Long, Bui Quang Hien and Pham Thi Bich Ngoc. Published in Asian Journal of Economics and Banking. Published by Emerald Publishing Limited. This article is published under the Creative Commons Attribution (CC BY 4.0) licence. Anyone may reproduce, distribute, translate and create derivative works of this article (for both commercial and non-commercial purposes), subject to full attribution to the original publication and authors. The full terms of this licence may be seen at http:// creativecommons.org/licences/by/4.0/legalcode

Funding: This research is funded by Vietnam National Foundation for Science and Technology Development (NAFODSTED) under grant number 502.01-2018.316.

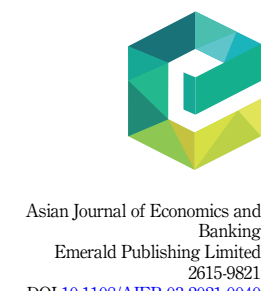

DOI 10.1108/AJEB-03-2021-0040 
instruments of monetary policy be activated and gradually take effect. Monetary turmoil phenomena created by mixed economies (systems including a planned economy and a market economy at the same time) have narrowed. Inflation is lowered and controlled to be more stable than before reform. Capital markets were formed after nearly a decade of economic reform (1990 in China, 2000 in Vietnam). On the other hand, Vietnam's accession to the World Trade Organization is 6 years later than China (China in 2001, Vietnam in 2007). These show that China always implements important steps in reform and achieves results before Vietnam.

There are similarities as well as differences in the economy between Vietnam and China (Duong and Le, 2007). Both countries pursue the market-oriented economy, the same pattern of economic reform, development and integration process. Particularly, Vietnam follows the socialist-oriented market economy. China follows a "socialist market economy with Chinese characteristics. The political systems of two countries have certain similarities. Similarities may come from the success of China's economic reform policies, and these policies are always ahead of Vietnam (Ma, 1999; Dao and Vu, 2008). Moreover, in terms of economics, if a country accepts and operates under a market mechanism, relations in that economy will also have to follow the rules of the market. This leads to similarities in results. However, the size of two economies is different. The capacity of influence on economics and politics is also different (Duong and Le, 2007; VNEP, 2016). Furthermore, in terms of geography and history, China is less influenced by political and economic changes in the world than Vietnam. In fact, China is an important element which contributes to the establishment of international relations in general and in the economic field in particular. In the opposite direction, Vietnam is strongly affected by these relations.

In the quantity theory of money (QTM), the relation between money stock $(M)$ and price level $(P)$ can be expressed through the equation $M V=P Y$ (Mankiw, 2016) where $M$ is the money supply, $V$ is the velocity of circulation of money, $Y$ is the real output and $P Y$ is the nominal output. The velocity of circulation of money is defined as the average amount of one unit of money circulated in the economy to pay for goods and services during a given period of time. Gross domestic product (GDP) is chosen as the variable representing the output, and $P$ is chosen as the deflator (GDP deflator). According to Chow and Shen (2005) mentioned the work of Friedman, there are limitations in the equation $M V=P Y$ because in practice this relation is not really accurate. In the equation, with $Y$ held constant, $P$ tends to increase as $M$ increases; with $M$ held constant, $P$ tends to increase as $Y$ decreases and with $P$ held constant, $Y$ tends to increase as $M$ increases. In the long run, the QTM is limited for several reasons. First, interest rate affects $V$, and this effect may not be constant in the long run. Second, the equation mentioned can be transformed into $M / P=Y / V$. This equation describes a demand for money equation responding to changes in income. In fact, the demand for money equation is influenced not only by income but also by interest rate and other factors $(m-p)=f(S, O C)$ where $(m-p)$ denotes the real money demand and $S, O C$ represents variables that show opportunity costs of holding money.

This study focuses on analyzing the relation of three macro-variables, including money supply real output and price level. Although this issue seems to be simple and obvious, previous studies about it are only conducted in other countries and China but not Vietnam (Chow and Shen, 2005; Aksoy and Piskorski, 2006; Budina et al., 2006; Homaifar and Zhang, 2008; Haug and Dewald, 2010; Anh and Thuy, 2013; Truong, 2013). In addition, limited data can be a reason why empirical research on this issue has not performed in Vietnam in previous studies. What is the relation between these three variables when two countries have many similarities in terms of economics and politics but have different economic scales? This paper will examine the relationship between money supply, inflation and output in Vietnam during the period 1986-2016 and in China during the period 1978-2008. After 30 years of reform, the study aims to demonstrate the existence of the relation between these variables and expect a new finding when using new quantitative techniques in time series data 
processing. Accordingly, the study contributes to shed light on the interaction between variables mentioned in the area of monetary policy management.

The paper is organized as follows. Section 1 highlights briefly the achievement of economic reform as well as the similarities and differences in the economy between Vietnam and China. This section also mentions the QTM, $M V=P Y$ and its limitation. Section 2 presents the methodology in the error correction model (ECM) following vector autoregression model (VAR) structure and canonical cointegration regression (CCR) for the multivariate variable. From this, the model specifications and data source are described in Vietnam and China case studies. The result of empirical study is presented in Section 3, which discusses the outcomes. One interesting result is that the different parameters of estimation between two countries are with different economic scales. In Vietnam, the expected inflation and output growth have a strong impact on inflation. In contrast, the inflation in China is strongly affected by money supply growth and output growth. Another noteworthy thing is that the increasing money supply to stimulate investment and boost economic growth in Vietnam is less effective than in China. In addition, the impact of income on money demand in Vietnam is much lesser than in Vietnam. The conclusion is shown in Section 4, which emphasizes some remarkable findings.

\section{Methodology}

\subsection{Research model}

Based on the equation $M V=P Y$, the study proposes models with variables that can interact with each other. The error correction model and the vector autoregression model (ECM-VAR) are used, and then canonical cointegration regression (CCR) is applied with an expectation that regression results are reliable when the phenomenon of serial correlation and endogeneity is adjusted.

$$
\left[\begin{array}{c}
\Delta \log \left(P_{t}\right) \\
\Delta \log \left(Y_{t}\right) \\
\Delta \log \left(M 2_{t}\right)
\end{array}\right]=\left[\begin{array}{c}
a_{1} \\
a_{2} \\
a_{3}
\end{array}\right]\left[\begin{array}{c}
\Delta \log \left(P_{t-1}\right) \\
\Delta \log \left(Y_{t-1}\right) \\
\Delta \log \left(M 2_{t-1}\right)
\end{array}\right]+\left[\begin{array}{c}
b_{1} \\
b_{2} \\
b_{3}
\end{array}\right]
$$

\subsection{Data research}

In Vietnam, data are collected from 1986 to 2016 from the World Bank (WB), the International Monetary Fund (IMF), the State Bank of Vietnam (SBV) and Asset Macro in the UK (http:// assetmacro.com). GDP and consumer price index (CPI) are chosen as variables representing the output variable (symbol $Y$ ) and the price variable (symbol $P$ ). GDP is collected directly from World Development Indicators (WDI) of WB with the original price in the base year 2010. The CPI is taken from the IMF with the comparative price of 2010 for the period 19952016. For the period 1986-1994, the CPI is collected from the IMF with the comparative price of 2005 and transferred to the original price of 2010 by applying the author's formula (3). $Y$ and $M 2$ variables are valued variables. The CPI variable is in percentage form. $M 2$ money supply is collected from the IMF, SBV and Asset Macro with comparison.

In China, variables including $M 2$ money supply, the retail price index and GDP are used to represent money supply $M 2$, price level $P$ and output $Y$. The data are derived from the study of Chow and Shen (2005) for the period 1952-2002 and from China Statistical Yearbook of the National Bureau of Statistics (NBS) of China for the period 2003-2008. The data for the period 1952-2002 are taken from the NBS, but estimates are similar to the methods that the author used when the data are not directly available (see data description of Chow and Shen (2005)).

$$
C P I(t)_{s s 2010}=\frac{C P I(t)_{s s 2005}}{C P I(2010)_{s s 2005}} \times 100
$$

Money supply, inflation and output

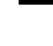


3. Empirical result

\subsection{Unit root test and Johansen cointegration test}

The study uses unit root test to test the stationary of variables, for the case of Vietnam (19862016) and China (1978-2008). At the first difference, results show that the null hypothesis of a unit root for all variables considered can be rejected. This means that variables stop at the first difference (Table 1). After testing for stationary, Johansen cointegration test is conducted. A value of $1 \%$ (or $5 \%$ ) is greater than the value of trace statistics for both Vietnam and China (Tables 2 and 3). Results indicate that there exists a long-term relationship between variables $\log \left(M 2_{t}\right), \log \left(P_{t}\right), \log \left(Y_{t}\right)$. This is the basis for further analysis.

\subsection{Volatility of price level and inflation}

The equation $M V=P Y$ can be rewritten as the formula $P=V(M / Y)$. Accordingly, the price level $P$ is influenced by two factors, namely money supply and output. $M$ variable is $M 2$, and $Y$ variable is the real GDP. $M 2$ money supply is chosen because interest rate may have a stronger impact on $M 1$ money demand than $M 2$ money demand. Increasing in interest rate will make $M 1$ money demand be likely to decrease due to the relationship with the profitability of deposit. In the case of Vietnam, Figure 1 shows that $\log (P)$ has a long-term positive relationship with $\log (M / Y)$ and has a nearly linear relation. The price level $P$ is the consumer price index in Vietnam with the base year 2010. In the case of China, although the starting point of the curve in Figure 2 is different from Vietnam, the positive relationship between the price level $P$ and $M 2 / Y$ is still quite obvious. The price level $P$ is the retail price index of the base year 1978 and is selected similarly to the research of Chow and Shen (2005).

Table 1.

\begin{tabular}{lcccc}
\hline & \multicolumn{2}{c}{ Vietnam $(1986-2006)$} & \multicolumn{2}{c}{ China (1978-2008) } \\
Variable & Zero difference & First difference & Zero difference & First difference \\
\hline $\log (Y)$ & -1.394 & $-3.459^{* 5}$ & 0.840 & $-5.88 *^{* 1}$ \\
$\log (P)$ & $-2.727^{* 10}$ & $-9.669 * 1$ & -0.377 & $-4.332 * *^{* 11}$ \\
$\log (M 2)$ & -1.248 & $-7.746^{* 1}$ & 0.605 & $-2.683^{* 10}$ \\
Note(s) $: *^{1},{ }^{5}$, and ${ }^{10}$ denote the significance at the $1 \%, 5 \%$, and $10 \%$ levels, respectively &
\end{tabular}

Results of unit root test Note(s): ${ }^{* 1},{ }^{* 5}$, and $*^{10}$ denote the significance at the $1 \%, 5 \%$, and $10 \%$ levels, respectively

Table 2.

Results of Johansen cointegration test forlog $\left(M 2_{t}\right), \log \left(P_{t}\right)$, and $\log \left(Y_{t}\right)$ for the case Vietnam

\begin{tabular}{lcccc}
\hline & & & \\
The number of cointegrating relations & Eigenvalue & Trace statistics & $\begin{array}{c}\text { Critical value } \\
1 \text { Percent } \\
\text { Critical value }\end{array}$ \\
\hline 0 & - & 80.76 & 29.68 & 35.65 \\
1 & 0.88 & $19.13^{* 1}$ & 15.41 & 20.04 \\
2 & 0.36 & $6.24 * 5$ & 3.76 & 6.65 \\
Note(s): ${ }^{1}$ and $* 5$ denote the significance at the $1 \%$ and $5 \%$ levels, respectively & \\
\end{tabular}

Table 3.

\begin{tabular}{lcccc}
\hline The number of cointegrating relations & Eigenvalue & Trace statistic & $\begin{array}{c}5 \text { Percent } \\
\text { Critical value }\end{array}$ & $\begin{array}{c}1 \text { Percent } \\
\text { Critical value }\end{array}$ \\
\hline 0 & - & 48.63 & 34.91 & 41.07 \\
1 & 0.56 & $23.34^{* 1}$ & 19.96 & 24.60 \\
2 & 0.37 & $8.86^{* 5}$ & 9.42 & 12.97 \\
Note(s): ${ }^{* 1}$ and ${ }^{5}$ denote the significance at the $1 \%$ and $5 \%$ levels, respectively \\
\end{tabular}




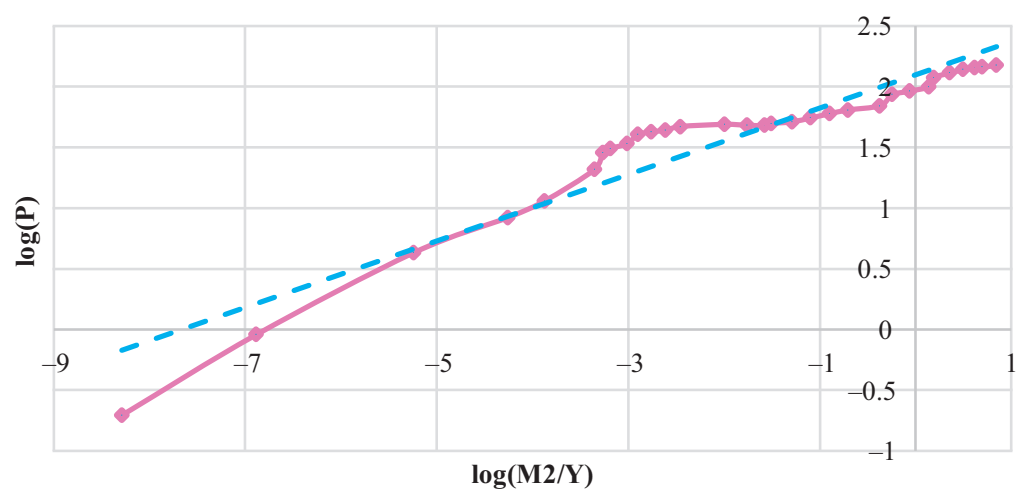

Money supply, inflation and output

Source(s): WDI, IMF, and assetmacro.com

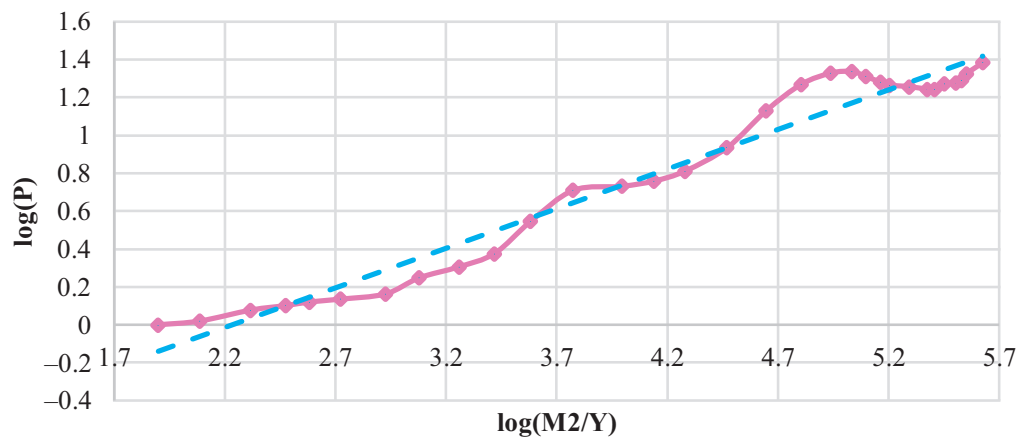

Figure 2. Plotting $\log (P)$ against $\log (M 2 / Y)$ for Chinese economy in the period 1978-2008

Source(s): WDI, IMF, and assetmacro.com

$$
\begin{gathered}
\log (P)=4.8306+0.6302 \log (M 2 / Y) \\
\log (P)=-0.9342+0.4182 \log (M 2 / Y)
\end{gathered}
$$

OLS regression results which show the impact of $M 2 / Y$ on the level price $P$ are presented in equations (3) and (4), respectively, for Vietnam in the period 1986-2016 and for China in the period 1978-2008 after 30 years of reform (Table 4). The estimated coefficients show no big significant difference between the period 1952-2002 and the period 1978-2008. Specifically, the elasticity of $\log (P 2)$ is 0.374 in the period 1952-2002 (Chow and Shen, 2005) and 0.418 in the period 1978-2008. In Vietnam, the elasticity (0.630) of $\log (M 2 / P)$ against $\log (P)$ is larger than that of China but not so different. Lag 1 of the residuals of the corresponding OLS model is saved as an independent variable. This variable is used to represent the adjustment coefficient in the ECM-VAR for the inflation estimation model $\Delta \log (P)$. The regression results are rewritten as formulas (5) and (6) for Vietnam and China, respectively, with the same data length as in the Ordinary Least Squares (OLS) model. There are similarities in the regression results for both Vietnamese and Chinese economies. Results in Table 5 show the inflation in year $t$ in Vietnam and China affected by last year's inflation and the corresponding increase in money supply in the year studying. However, the increase of money supply in the previous year does not suggest any impact on the current year's inflation. According to the 
Fisher's QTM, price level changes are based on changes in the quantity of money. Changes in the price level $P$ and changes in money supply are proportional. However, in fact, there is an impact lag between the time a policy is enacted and the time such policy influences the economy under changes in the economic situations. The formula does not mention the period of time required from the moment the central bank begins to implement the monetary policy instruments that affect macroeconomic factors in the economy. The study of Chen (2006) on the relation between the lag of money supply and inflation for Chinese economy indicates that inflation is affected by money supply with at least a five-month lag. Because the model is estimated by year, the increase in money supply will affect inflation in that year. The study of Chow and Shen (2005), which estimates inflation for Chinese economy during the period 1952-2002, also reaches the same conclusion. However, there is a difference in the adjustment coefficient towards the equilibrium in these two countries. In Vietnam, the adjustment coefficient of the ECM model is negative and not statistically significant. This suggests that the model, in the long run, is not self-adjusting to the equilibrium. Meanwhile, inflation estimation for Chinese economy indicates that in the long run, the model can be adjusted to the equilibrium with the adjustment factor of -0.223 at a $1 \%$ significance level. The regression shows no big difference between China and Vietnam when considering the effect of last year's inflation on current inflation. Specifically, the elasticities are 0.558 and 0.656 in China for the period 1952-2002 (Chow and Shen, 2005) and the period 1978-2008, respectively. In Vietnam, both estimated coefficients are not significantly different from each other (0.439) compared to the case of China. However, there are differences in the impact on inflation in these two countries when assessing the impact factors $(0.617$ is much higher than 0.216). This shows that inflation in Vietnam reacts more strongly to changes in the monetary policy than in China.

$$
\begin{aligned}
\Delta \log (P)_{t}= & -0.0145+0.6168 \Delta \log (M 2 / Y)_{t}+0.4392 \Delta \log (P)_{t-1} \\
& -0.2253 \Delta \log (M 2 / Y)_{t-1}-0.0732 u_{t-1}
\end{aligned}
$$

Table 4.

OLS model for the price level for Vietnam and China

\begin{tabular}{lccc}
\hline Variable & Vietnam (1986-2016) & China (1978-2008) & China (1952-2002) \\
\hline $\log (M 2 / Y)_{t}$ & $0.630^{* 1}$ & $0.418^{* 1}$ & $0.374^{* 1}$ \\
Constant & $4.831^{* 1}$ & $-0.934^{* 1}$ & $-0.713^{* 1}$ \\
Number of Observations & 31 & 31 & 51 \\
$R$ squared & 0.913 & 0.966 & 0.965 \\
Note(s): ${ }^{* 1}$ denote the significance at the $1 \%$ level & & \\
\hline
\end{tabular}
Table 5.
Error correction model
for inflation in the case of Vietnam and China

\begin{tabular}{lccc}
\hline Variable & Vietnam $(1986-2016)$ & China (1978-2008) & China (1952-2002) \\
\hline$\Delta \log \left((M 2 / Y)_{t}\right)$ & $0.617^{* 1}$ & $0.216^{* 10}$ & $0.160^{* 1}$ \\
$\Delta \log \left(P_{t-1}\right)$ & $0.439{ }^{* 5}$ & $0.656^{* 1}$ & $0.558^{* 1}$ \\
$\Delta \log \left((M 2 / Y)_{t-1}\right)$ & -0.225 & -0.0629 & -0.0307 \\
$u_{t-1}$ & -0.0732 & $-0.223^{* 1}$ & $-0.169 * 1$ \\
Constant & -0.0145 & -0.00123 & 0.000951 \\
Number of observations & 29 & 31 & 49 \\
$R$ squared & 0.880 & 0.643 & 0.658 \\
Note(s): ${ }^{1},{ }^{* 5}$ and ${ }^{* 10}$ denote the significance at the $1 \%, 5 \%$ and $10 \%$ levels, respectively & \\
\hline
\end{tabular}




$$
\begin{aligned}
\Delta \log (P)_{t}= & -0.0012+0.2164 \Delta \log (M 2 / Y)_{t}+0.6556 \Delta \log (P)_{t-1} \\
& -0.0629 \Delta \log (M 2 / Y)_{t-1}-0.223 u_{t-1}
\end{aligned}
$$

\subsection{Money supply, inflation and output}

The relation between money supply, inflation and output are regressed by the ECM-VAR model. Tables 6 and 7 show the comparison of regression results for money supply, inflation and output in Vietnam during the period 1986-2016 and in China during the period 19782008 after 30 years of reform and the period 1952-2002 according to the research of Chow and Shen (2005). The results of the ECM-VAR model show that there is a downside when some important impacts are not statistically significant, and expected signs are different from expectation. For example, the impact of money supply on growth is not statistically significant for both Vietnam and China. Money supply and growth which have negative impacts on inflation are statistically significant at 5 and $10 \%$, respectively in the case of Vietnam. Results of the autocorrelation test and the normality test of residuals are violated in some cases. In Vietnam, there is an autocorrelation phenomenon when considering $\operatorname{LM}(2)$ at a significance level of $5 \%$. The residuals are not normally distributed when $\Delta \log \left(P_{t}\right)$ is a dependent variable at a 5\% significance level. In China for the period 1952-2002, autocorrelation occurs in $\operatorname{LM}(1)$ at the significance level of $1 \%$, and the residuals are not normally distributed at a significance level of $5 \%$ when $\Delta \log \left(P_{t}\right)$ and $\Delta \log \left(Y_{t}\right)$ are considered dependent variables. For the period 1978-2008 (30 years after reform), results show that the residuals are normally distributed, and there is no autocorrelation in the model. However, the number of variables that have statistical significance is not like what expected. For example, while it is often discussed in the monetary policy that an increase in money supply brings upward pressure on inflation (Friedman, 1970), there is no such evidence of ECM outcomes. The study continues to run the CCR model with an expectation that regression results are reliable when the phenomenon of serial correlation and endogeneity is adjusted (Wang and $\mathrm{Wu}, 2012$ ). The regression results suggest that there is a similarity in the relation between the above mentioned three variables for both economies. The interaction is consistent with the QTM. An increase in money supply leads to an increase in inflation and promotes growth. Inflation and growth have impacts on inflation and growth in the future. Money demand is affected by income. The results of the CCR model are shown in Table 8.

In terms of inflation, all variables, including $M 2$ money supply growth, inflation and output growth, in the previous year influence inflation in the current year in both cases of Vietnam and China. First, the regression results show that inflation in Vietnam is strongly affected by inflation in the previous year. If inflation in the previous year is on an upward trend, it is likely that inflation in the following year will increase. On the other hand, due to a time lag in monetary policy implementation, inflation is difficult to control and may reverse in the next year. For the Chinese economy, last year's inflation also affects inflation in the current year, but this effect is weaker than that in Vietnam $(0.180<0.381)$. This suggests that using the lagged value of inflation as expected inflation is inadequate since the estimated coefficient of Vietnam is almost two times higher than that of China. Second, output growth in the previous year increases pressure on inflation in the current year. This effect can be explained by the aggregate supply-aggregate demand model (AS-AD). When the economy has not reached potential output, an increase in the level of output will lead to an increase in the price level. The impact factor of output growth on inflation in Vietnam is approximately two times smaller than that of China $(0.332<0.657)$. This implies that growth in Vietnam just partly influences inflation. Meanwhile, growth seems to have a huge impact on inflation in China. Third, a rise in $M 2$ money supply growth in the previous year exerts upward pressure on the current year's inflation. In the money market, an increase in money supply will lead to a decrease in the base rate. Reduced interest rate helps stimulate investment and contribute to a
Money supply, inflation and output

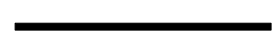


AJEB

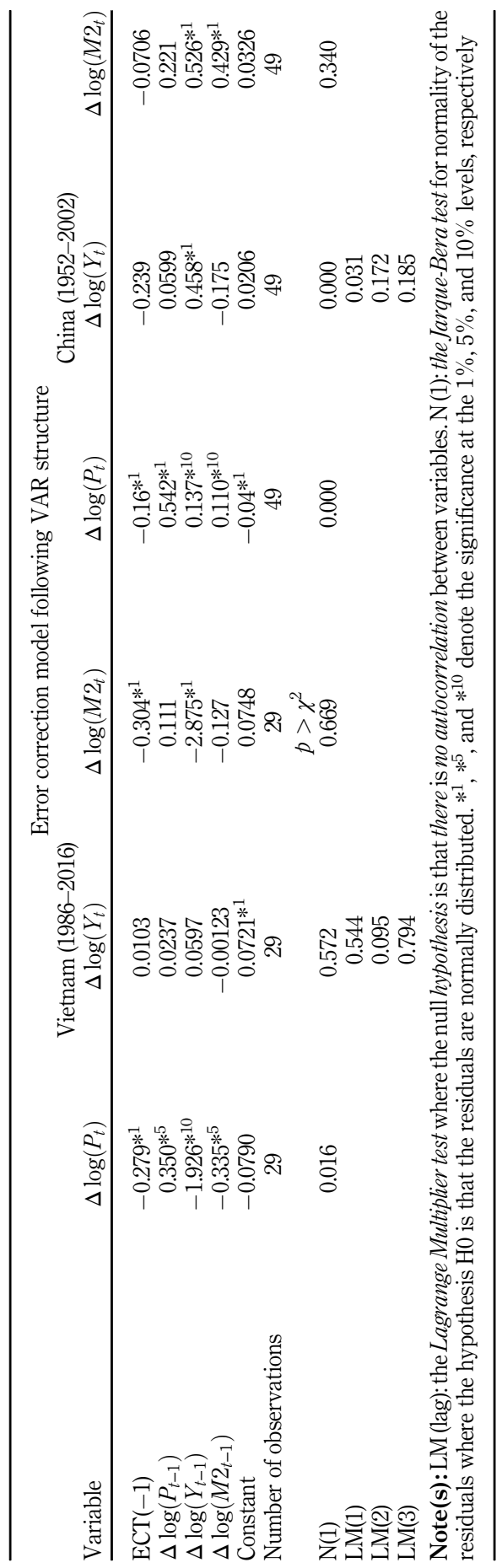

Table 6.

Error correction model of $\Delta \log \left(M 2_{t}\right)$,

$\Delta \log \left(P_{t}\right), \Delta \log \left(Y_{t}\right)$ in Vietnam and China (1952-2002) 


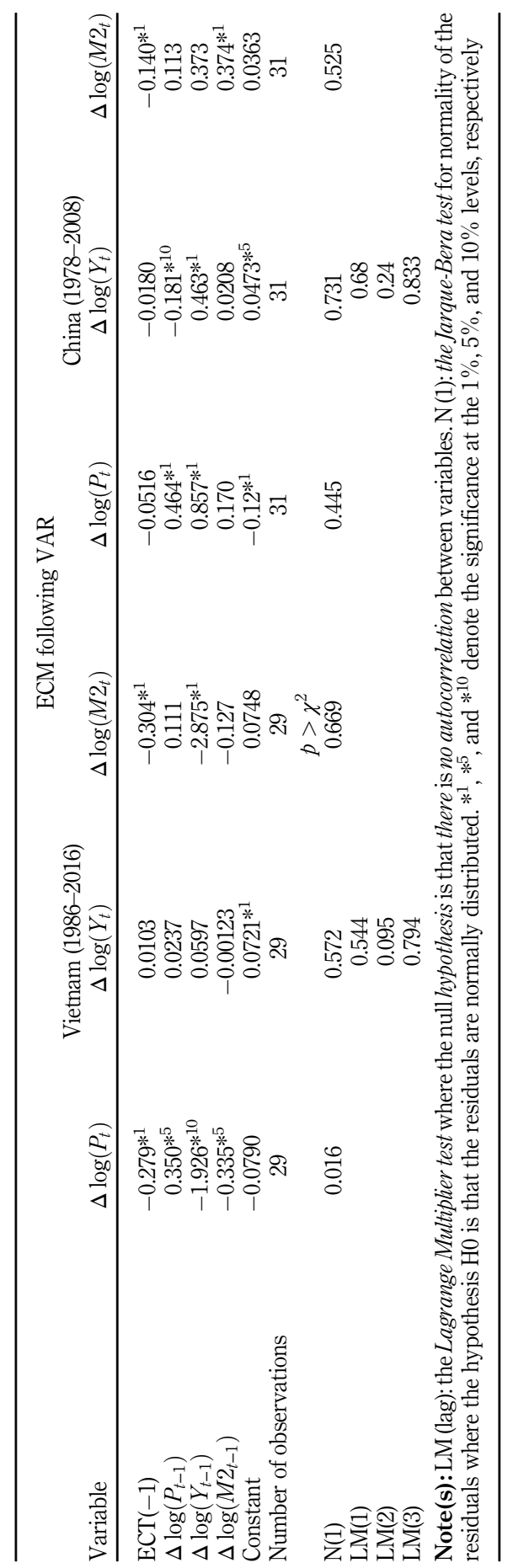

Money supply, inflation and output

Table 7. Error correction model of $\Delta \log \left(M 2_{t}\right)$, $\Delta \log \left(P_{t}\right), \Delta \log \left(Y_{t}\right)$ in Vietnam and China (1978-2008) 
AJEB

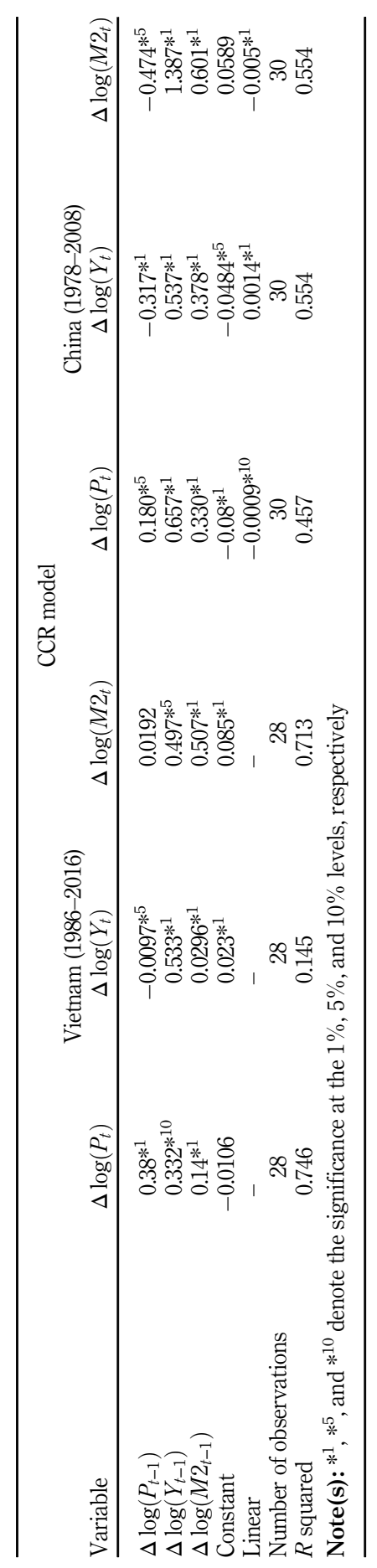

Table 8.

Canonical

cointegration

regression model of

$\Delta \log \left(M 2_{t}\right), \Delta \log \left(P_{t}\right)$,

$\Delta \log \left(Y_{t}\right)$ in Vietnam

and China (1978-2008) 
rise in the aggregate demand. In the $\mathrm{AS}-\mathrm{AD}$ model, an increase in the aggregate demand results in an increase in the price leve,l which in turn raises inflation. Moreover, this is consistent with Friedman's finding in which inflation is a monetary phenomenon that happens when the quantity of money increases more rapidly than output (Friedman, 1970). There is a difference in the regression results for Vietnam and China. In Vietnam, the effect of $\Delta \log \left(M 2_{t-1}\right)$ on $\Delta \log \left(P_{t}\right)(0.137)$ is smaller than the effect of $\Delta \log \left(P_{t-1}\right)$ on $\Delta \log \left(P_{t}\right)(0.381)$. In contrast, in China, the effect of $\Delta \log \left(M 2_{t-1}\right)$ on $\Delta \log \left(P_{t}\right)(0.330)$ is greater than the effect of $\Delta \log \left(P_{t-1}\right)$ on $\Delta \log \left(P_{t}\right)(0.180)$. This interesting result shows that while money supply shocks influence inflation in Vietnam, there exist other factors that have strong impacts on inflation. Studies suggest that this result is appropriate for developing countries, like Vietnam. The regression results show that other effects come from expected inflation. In Vietnam, inflation is often volatile and sometimes the evolution of annual inflation is far away from inflation targeting (Do and Huong, 2014). This creates a psychological fear that inflation in the past will not be adjusted soon, continue to maintain and even increase in the next year. On the other hand, Vietnam has a relatively large open economy (VNEP, 2016). Inflation is not only affected by the implementation of fiscal and monetary policy and internal macroeconomic variables inside the economy but also external factors. External factors may be the exchange rate of dong against other currencies, world economic crises, political instability, etc. For instance, when China devalue its currency to boost exports, Vietnam also has to devalue the dong (VND) to increase the competitiveness of its exports. Meanwhile, the cost of domestic production increases due to a rise in the price of inputs. Currency devaluation can lead to an increase in domestic production costs. This can raise inflation. At the same time, forecasting scenarios and macroeconomic policies are difficult to anticipate. In the opposite direction, China is the second largest economy in the world. China's inflation is less affected by other factors than small economies' inflation. Obviously, if Vietnam devalues its currency first, it is unlikely that this will affect other major countries or make them reconsider their macroeconomic policies.

In terms of output, output growth is positively affected by $M 2$ money supply growth and output growth in the previous year and is negatively affected by last year's inflation. First, results show that increasing money supply to stimulate investment and boost growth in Vietnam is less effective than in China $(0.0296>0.378)$. This implies that the quantity of money injected into the economy to use for investment growth is restricted, or investment efficiency is not high. Second, the negative impact of inflation and the positive impact of $M 2$ money supply growth in the previous year are very small in the case of Vietnam. Meanwhile, the regression results for China show that the signs of these two estimated coefficients are similar to those for Vietnam, but the impact is high. Previous studies suggest that inflation has a negative impact on growth (Ghosh and Phillips, 1998; Dammak and Helali, 2017). In Vietnam, the elasticity of expected inflation on output growth is low. According to the regression results, this may be due to the strong impact of the expected output growth (0.533) and the impact of other factors other than money supply and inflation. Third, there is a similarity in the impact factor of the expected output growth on output growth for both Vietnam (0.533) and China (0.537).

\section{Conclusion}

After 30 years of reform, both Vietnam and China have made a successful revolution from a planned economy to a market economy, creating tremendous economic development. Through empirical evidence, the study demonstrates that the relationship between money supply, inflation and output is still true in the case of transition economies. The law of the market is correct, though the orientation of certain market economies is different from that of
Money supply, inflation and output

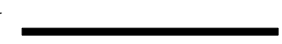


developed countries with a long-standing market economy. In addition, the study shows that the degree of the interaction between money supply, inflation and output varies responding to particular conditions of two countries, in which both pursue a market-oriented mechanism but differ in the scale of the economy.

\section{References}

Aksoy, Y. and Piskorski, T. (2006), "US domestic money, inflation and output", The Journal of Monetary Economics, Vol. 53, pp. 183-197, doi: 10.1016/j.jmoneco.2005.01.002.

Anh, N.T. and Thuy, N.T. (2013), "Mối quan hệ tương tác giữa tỷ giá, sản lượng và lạm phát tại Việt Nam giai đoạn 2001-2011", Nghiên cứu kinh tế, Vol. 419, pp. 3-12.

Budina, N., Maliszewski, W., de Menil, G. and Turlea, G. (2006), "Money, inflation and output in Romania 1992-2000", Journal of International Money and Finance, Vol. 25, pp. 330-347, doi: 10. 1016/j.jimonfin.2005.11.006.

Chen, H. (2006), "An empirical study of Chinese inflation time lag”, International Business Research, Table 2, pp. 42-47.

Chow, G.C. and Shen, Y. (2005), "Money, price level and output in the Chinese macro economy", AsiaPacific Journal of Accounting and Economics, Vol. 12, pp. 91-111, doi: 10.1080/16081625.2005. 10510653.

Dammak, T.B. and Helali, K. (2017), "Threshold effects on the relationship between inflation rate and economic growth in Tunisia", The Journal of International Economics, Vol. 31, pp. 310-325, doi: 10.1080/10168737.2017.1289546.

Dao, X.S. and Vu, Q.T. (2008), Đổi mới ở Việt Nam: Nhớ lại và suy ngẫm, Nhà xuất bản tri thức.

Do, T.P.H. and Huong, D.K. (2014), "Đánh giá sự biến động của lạm phát và ngụ ý trong điều hành chính sách tiền tệ tại Việt Nam”, Tạp chí nghiên cúu kinh tế, Vol. 431, pp. 47-52.

Duong, Van.A. and Le, M.D. (2007), Economic Reforms in China and Vietnam: A Brief Comparison, Cent Inst Econ Manag Hanoi.

Friedman, M. (1970), Counter-Revolution in Monetary Theory, Occasional paper 33, Institute of Economic Affairs.

Ghosh, A. and Phillips, S. (1998), Warning: Inflation May Be Harmful to Your Growth, Staff Pap 45, IMF, pp. 672-710, doi: 10.2307/3867589.

Haug, A.A. and Dewald, W.G. (2010), Money, Output and Inflation in the Longer Term: Major Industrial Countries 1880-2001, p. 1760.

Homaifar, G.A. and Zhang, N. (2008), "Long run relationship between money, output, and inflation”, Economia Internazionale/International Economics, Vol. 61, pp. 687-709.

Ma, J. (1999), The Chinese Economy in the 1990s, Springer.

Mankiw, G. (2016), Macroeconomics, 9th ed., Worth Publishers, New York.

Oanh, N.X. (2001), Đổi mới: Vai nét lớn Của một Chính sách kinh tế Việt Nam, Nhà xuất bản TP. Hồ Chí Minh.

Truong, M.T. (2013), "Mối quan hệ giữa lạm phát và tăng trưởng kinh tế: Nghiên cứu thực nghiệm ở Việt Nam", Phát triển kinh tế, Vol. 278, pp. 02-12.

VNEP (2016), Phụ thuộc kinh tế giữa Việt Nam - Trung Quốc, Nhà xuất bản tài chính, Hà Nội.

Wang, Q. and Wu, N. (2012), "Long-run covariance and its applications in cointegration regression", The Stata Journal, Vol. 12, pp. 515-542.

\section{Further reading}

Chow, G.C. (1987), "Money and price level determination in China”, Journal of Comparative Economics, Vol. 11, pp. 319-333. 
Knell, M. and Stix, H. (2005), "The income elasticity of money demand: a meta-analysis of empirical results", Journal of Economic Surveys, Vol. 19, pp. 513-533, doi: 10.1111/j.0950-0804.2005.00257.x.

Kumar, S. (2014), "Money demand income elasticity in advanced and developing countries: new evidence from meta-analysis", Applied Economics, Vol. 46, pp. 1873-1882, doi: 10.1080/00036846.

Money supply, inflation and output 2014.887195.

Sriram (1999), Survey of Literature on Demand for Money: Theoretical and Empirical Work with Special Reference to Error-Correction Models, Work Pap No. 99/64, IMF, pp. 1-77.

Zuo, H. and Park, S.Y. (2011), "Money demand in China and time-varying cointegration", China Economic Review, Vol. 22, pp. 330-343, doi: 10.1016/j.chieco.2011.04.001.

\section{Corresponding author}

Pham Thi Bich Ngoc can be contacted at: ngoc.phamthibich@hoasen.edu.vn

For instructions on how to order reprints of this article, please visit our website:

www.emeraldgrouppublishing.com/licensing/reprints.htm

Or contact us for further details: permissions@emeraldinsight.com 